\title{
PENINGKATAN SIKAP KEDISIPLINAN MELALUI APEL PAGI SISWA MIN NGLAWU SUKOHARJO
}

\author{
Warsito \\ Madrasah Ibtidaiyah Negeri Nglawu Sukoharjo \\ Warsito.syafiq07@gmail.com
}

\begin{abstract}
Abstrak
Penelitian ini bertujuan untuk mengetahui peningkatan sikap kedisiplinan siswa kelas VC MIN Nglawu Sukoharjo Tahun ajaran 2016/2017 melalui apel pagi siswa. Jenis penelitian ini adalah Penelitian Tindakan Kelas. Penelitian ini terdiri dari 2 siklus. Setiap siklus tersebut meliputi tahap perencanaan, tindakan, observasi, dan refleksi. Subjek penelitian adalah siswa kelas VC MIN Nglawu Sukoharjo berjumlah 38 anak terdiri dari 23 siswa laki-laki dan 15 siswa perempuan. Metode pengumpulan data dalam penelitian ini adalah observasi. Instrumen penelitian yang digunakan adalah lembar observasi. Kriteria peningkatan kedisiplinan yang dicapai siswa dilihat dari adanya perubahan kearah perbaikan.

Hasil penelitian menunjukkan bahwa dengan kegiatan apel pagi dapat meningkatkan sikap kedisiplinan siswa. Hal itu terlihat dari hasil observasi pada siswa persentase nilai pra tindakan sebesar 26,32\% atau sebanyak 10 siswa yang masuk kategori disiplin. Tindakan I meningkat menjadi 39,48\% atau sebanyak 15 siswa. Sedangkan pada Tindakan II meningkat menjadi 65,79\% atau sebanyak 25 siswa.
\end{abstract}

Kata Kunci : Kedisiplinan, Apel Pagi

\section{THE IMPROVEMENT OF DISCIPLINARY THROUGH MORNING ROLL STUDENT MIN NGLAWU SUKOHARJO}

\author{
Warsito \\ Madrasah Ibtidaiyah Negeri Nglawu Sukoharjo \\ Warsito.syafiq07@gmail.com
}

\begin{abstract}
This study aims to determine: Improvement of students' disciplinary attitude on class VC MIN Nglawu Sukoharjo Class academic year 2016/2017 through student morning roll. The type of research is Classroom Action Research. The study consists of 2 cycles. Each cycle has planning, action, observation, and reflection phases. The subjects are students of class VC MIN Nglawu Sukoharjo, it is 38 students which consists of 23 male students and 15 female students. Data collection method of the research is observation. The research instrument used is observation sheet. Criteria of student discipline improvement is looked from the changes towards improvement. The results shows that uses morning roll can improve student discipline attitude. It can be seen from the result of observation on student percentage of pre-action equal to $26,32 \%$ or as many as 10 students who belongs to discipline category. First step increases to $39.48 \%$ or as many as 15 students. While in second step, it increases to $65.79 \%$ or as many as 25 students. Students show a change in disciplinary attitude.
\end{abstract}

Keywords: Discipline, Morning roll 


\section{PENDAHULUAN}

Peningkatan mutu pendidikan di Indonesia salah satunya melalui pencapaian hasil belajar siswa dalam pembelajaran di sekolah. Kegiatan pembelajaran di sekolah dipengaruhi oleh dua faktor yang penting yaitu guru dan siswa. Keberhasilan pembelajaran siswa, sangat dipengaruhi oleh sikap siswa itu sendiri dalam belajar. Salah satu sikap siswa dalam belajar yaitu sikap kedisiplinan. Sikap kedisiplianan siswa adalah sikap yang harus ditanamkan siswa dari pendididikan anak usia dini, pendidikan dasar, pendidikan menengah bahkan sampai pendidikan tinggi. Sikap kedisiplinan siswa akan berpengaruh terhadap hasil belajar siswa seperti hasil penelitian yang dilakukan Alimaun, Imam (2015:77) yang menyatakan bahwa : ada pengaruh yang signifikan kedisiplinan siswa terhadap hasil belajar siswa. Sikap kedisiplinan siswa tidak muncul begitu saja tetapi perlu dipupuk melalui pendidikan dan penanaman kebiasaan baik di lingkungan keluarga, masyarakat dan sekolah.

Banyak kasus atau permasalahan mengenai rendahnya sikap kedisiplinan siswa terutama tingkat sekolah dasar yang pada akhirnya berdampak pada hasil belajar yang rendah pula. Sebagai contoh permasalahan yang diangkat oleh Alimaun, Imam (2015:77), di Sekolah Dasar se-Daerah Binaan R. A. Kartini Kecamatan Kutoarjo Kabupaten Purworejo mengenai rendahnya kedisiplinan sehingga berdampak pada hasil belajar siswa.

Permasalahan tentang kurangnya sikap kedisiplinan siswa juga dialami oleh siswa-siswa kelas VC Madrasah Ibtidaiyah Negeri Nglawu Sukoharjo tahun ajaran 2016/2017. Menurut hasil observasi yang dilakukan dikelas VC oleh peneliti dapat ditarik kesimpulan bahwa tingkat kedisiplinan di kelas tersebut rendah. Hal ini tampak dari jumlah siswa yang masuk kategori disiplin tidak lebih dari 10 siswa dari 38 siswa. Rendahnya kedisiplinan siswa baik dalam proses pembelajaran maupun tentang tata tertib disekolah dipengaruhi faktor internal dan eksternal. Faktor internal diantaranya yaitu, faktor dari bawaan siswa itu sendiri, faktor eksternal yaitu temanteman sebayanya baik yang ada diluar sekolah maupun didalam lingkungan sekolah dan faktor dari orang tua mereka dirumah.

Definisi disiplin sendiri menurut Prijodarminto dalam Tu'u (2004: 31) 
yaitu "sebagai suatu kondisi yang tercipta dan terbentuk dari serangkaian perilaku yang menunjukkan nilai ketaatan, kepatuhan, kesetiaan atau keteraturan atau ketertiban". Sedangkan menurut Mohammad Mustari (2011: 41) disiplin merupakan tindakan yang menunjukkan perilaku tertib dan patuh terhadap berbagai ketentuan dan peraturan yang berlaku. Menurut Mohhammad Mustari (2011: 41) disiplin adalah tindakan atau perilaku yang mewakili dan menunjukkan sikap perilaku tertib aturan serta patuh pada semua ketentuan dan aturan baik yang tertulis maupun tidak tertulis.

Berdasarkan uraian di atas, dapat disimpulkan bahwa kedisiplinan adalah kepatuhan yang diperlihatkan seseorang terhadap aturan dan tata tertib yang berlaku sehingga berperilaku tertib di lingkungannya. Kedisiplinan membuat siswa dapat memahami dan menyesuaikan diri dengan tuntutan lingkungan. Kedisiplinan juga menjadi cara dalam menyelesaikan tuntutan yang mungkin ingin ditunjukkan seseorang terhadap lingkungannya.

Salah satu upaya untuk meningkatkan sikap kedisiplinan siswa yaitu dengan melakukan apel pagi bagi siswa disekolah. Apel pagi merupakan kegiatan yang bertujuan dalam membentuk penanaman kedisiplian. Seperti pendapat yang dikutip dari M. Rasyid Nur yang menyatakan bahwa dengan menyisihkan 5-15 menit setiap pagi sebelum masuk kelas sesungguhnya ada banyak arahan atau nasehat yang dapat disampaikan. Arahan atau nasehat itu pula yang membantu mengarahkan peserta didik untuk menjadi lebih baik.

\section{METODE PENELITIAN}

Penelitian ini termasuk Penelitian Tindakan Kelas (Classroom Action Research). Hal itu sesuai dengan tujuan penelitian, yaitu meningkatkan prestasi belajar siswa. Rustam dan Mundilarto (2004: 1) mendefinisikan penelitian tindakan kelas adalah sebuah penelitian yang dilakukan oleh guru di kelasnya sendiri dengan jalan merancang, melaksanakan, dan merefleksikan tindakan secara kolaboratif dan partisipatif dengan tujuan untuk memperbaiki kinerjanya sebagai guru sehingga hasil belajar siswa dapat meningkat.

Desain penelitian ini menggunakan model Penelitian Tindakan Kelas (Classroom Action Research) yang dilaksanakan dengan 
mengikuti prosedur penelitian berdasarkan pada prinsip penelitian tindakan kelas. Menurut Kemmis dan Mc Taggart (Suharismi Arikunto, 2006:93) penelitian itu terdiri dari beberapa siklus. Sedangkan dalam siklus masih terdapat beberapa komponen yang harus diperhatikan oleh peneliti yaitu: (1) perencanaan (planning), (2) tindakan (action), (3) observasi (observation), dan (4) refleksi (reflection). Keempat kegiatan ini berlangsung secara berulang dalam bentuk siklus.

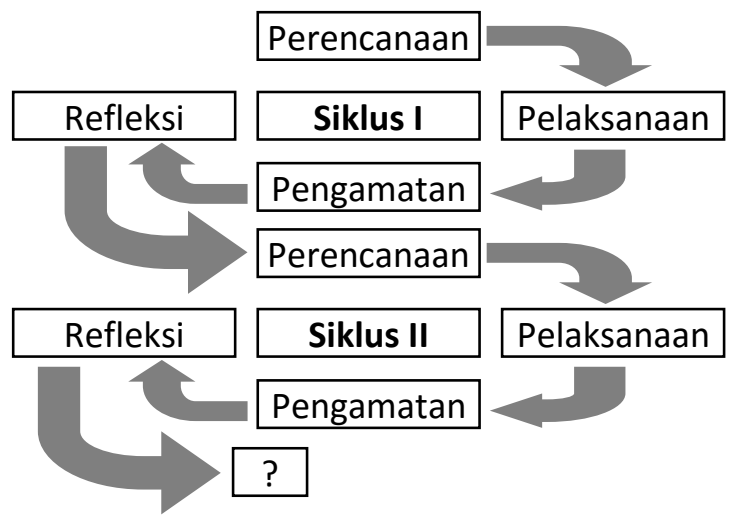

Gambar 1. Model Penelitian Tindakan

Berdasarkan gambar di atas, dapat dijelaskan bahwa keempat tahap dalam penelitian tindakan tersebut adalah unsur untuk membentuk sebuah siklus, dimana satu putaran kegiatan beruntun yang kembali kelangkah semula. Jadi, satu siklus adalah dari tahap penyusunan rancangan sampai dengan refleksi, yang tidak lain adalah evaluasi.

Subjek dalam penelitian ini adalah siswa kelas VC MIN Nglawu Sukoharjo. Jumlah siswa kelas VC MIN Nglawu Sukoharjo berjumlah 38 siswa yang terdiri dari 23 orang siswa lakilaki dan 15 orang siswa perempuan. Teknik pengumpulan data adalah cara yang dilakukan oleh peneliti untuk memperoleh data akurat dalam penelitian. Teknik pengumpulan data dalam penelitian ini adalah observasi. Observasi merupakan suatu proses yang kompleks, suatu proses yang tersusun dari berbagai proses biologis dan psikologis. Dua di antara yang terpenting adalah proses-proses pengamatan dan ingatan (Sutirno Hadi, 1986).

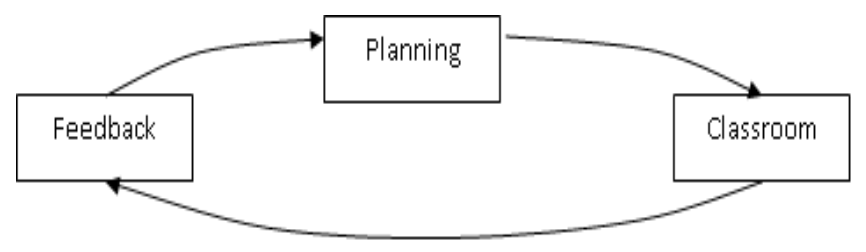

Gambar 2. Siklus Observasi (Hopkins, 1992: 243) dalam Amir (2007: 135)

Observasi adalah metode pengumpulan data di mana peneliti atau kolabolator mencatat infornasi sebagaimana yang mereka saksikan selama peneliti. Menurut Iskandar 
(2009: 181) observasi adalah pengamatan terhadap objek-objek yang dapat dijadikan sebagai sumber pengamatan. Kasbolah (2001: 51 - 52) mengemukakan bahwa observasi adalah semua kegiatan yang ditujukan untuk mengenali, merekam dan mendokumentasikan setiap indikator dari proses dan hasil yang dicapai (perubahan yang terjadi) baik yang ditimbulkan oleh tindakan terencana maupun akibat sampingannya.

Dalam penelitian ini peneliti menggunakan teknik observasi berperan serta (Participant observation). Dalam observasi ini peneliti terlibat dengan kegiatan sehari-hari orang yang sedang diamati atau digunakan sebagai sumber data penelitian. Sambil melakukan pengamatan, peneliti ikut melakukan apa yang dikerjakan oleh sumber data.

\section{HASIL DAN PEMBAHASAN}

Sebelum dilaksanakan sebuah tindakan yang berupa apel pagi untuk meningkatkan sikap kedisiplinan siswa, terlebih dahulu peneliti melakukan observasi, kemudian didapat hasil sebagai berikut :
Tabel 1. Deskripsi sikap kedisiplinan siswa awal

\begin{tabular}{ccc}
\hline Kategori & Jumlah siswa & Persentase \\
\hline Disiplin & 10 & $26,32 \%$ \\
\hline Belum disiplin & 28 & $73,68 \%$ \\
\hline
\end{tabular}

Setelah pemberian tindakan berupa apel pagi 3 kali dalam 1 minggu, kemudian didapatkan hasil sebagai berikut:

Tabel 2. Deskripsi sikap kedisiplinan siswa Siklus I

\begin{tabular}{ccc}
\hline Kategori & $\begin{array}{c}\text { Jumlah } \\
\text { siswa }\end{array}$ & Persentase \\
\hline Disiplin & 15 & $39,48 \%$ \\
\hline Belum disiplin & 23 & $60,52 \%$ \\
\hline
\end{tabular}

Melihat hasil dari tindakan I belum maksimal maka, dilanjutkan dengan pemberian tindakan II dengan lebih mengintensifkan apel yaitu 5 kali dalam 1 minggu dengan juga ditambah penguatan berupa pemberian hukuman dan hadiah, sehingga didapatkan hasil sebagai berikut :

Tabel 3. Deskripsi sikap kedisiplinan siswa Siklus II

\begin{tabular}{ccc}
\hline Kategori & $\begin{array}{c}\text { Jumlah } \\
\text { siswa }\end{array}$ & Persentase \\
\hline Disiplin & 25 & $65,79 \%$ \\
\hline Belum disiplin & 13 & $34,21 \%$ \\
\hline
\end{tabular}


Berdasarkan hasil pelaksanaan tindakan atau siklus I dan II maka dapat disimpulkan bahwa terjadi peningkatan sikap kedisiplinan siswa kelas VC MI Negeri Nglawu Sukoharjo. Dari data Pra Siklus jumlah siswa yang tuntas sejumlah 10 siswa atau 26,32\%, kemudian pada Siklus I dengan pemberian tindakan berupa apel pagi yang dilaksanakan 3 kali dalam seminggu, jumlah siswa yang tuntas meningkat menjadi 15 siswa atau 39,48\%. Dari hasil Siklus I sudah bisa terlihat peningkatan sikap disiplin siswa meskipun masih belum maksimal hasilnya. Masih banyak siswa yang menyepelekan karena merasa tidak ada efek jera dengan pelanggaran yang telah dilakukan. Di Siklus II menekankan pada perbaikan di siklus sebelumnya dengan pemberian tindakan berupa mengoptimalkan apel pagi dengan melaksanakanya lebih rutin yaitu 5 kali dalam seminggu ditambah dengan pemberian hukuman bagi siswa yang tidak ikut apel pagi tanpa alasan yang sesuai dan pemberian hadiah bagi 5 siswa yang masuk kategori paling disiplin.

Terbukti dari data hasil tindakan di Siklus II terjadi peningkatan jumlah siswa yang tuntas meningkat menjadi
25 siswa atau 65,79\%. Berdasarkan tindakan-tindakan tersebut, peneliti berhasil meningkatkan sikap kedisiplinan Pernyataan ini sesuai dengan pendapat Sastrohadiwiryo (2003) Pada umumnya sebagai pegangan dan meskipun tidak mutlak siswa dengan menerapkan apel pagi sekolah disertai hukuman dan hadiah dalam pelaksanaanya., tingkat dan jenis sanksi disiplin terdiri atas sanksi disiplin berat, sanksi disiplin sedang, sanksi disiplin ringan. Diperkuat Hurlock (1978: 84) menjelaskan empat unsur pokok disiplin yaitu: peraturan, hukuman, penghargaan, dan konsistensi.

\section{KESIMPULAN DAN SARAN}

Berdasarkan diskripsi hasil yang dicapai penelitian tindakan kelas, dapat disimpulkan bahwa penerapan apel pagi siswa dapat meningkatkan sikap kedisiplinan siswa MIN Nglawu Sukoharjo, dengan penambahan hukuman dan pemberian hadiah sebagai penguat motif internal. Hal ini ditunjukkan dari meningkatnya presentase jumlah siswa baik dari Prasiklus ke siklus I, maupun dari siklus I ke siklus II.

Penerapan apel pagi ini akan sangat efektif jika diikuti juga diseluruh 
kelas di MIN Nglwu sehingga tidak terkesan ada perlakuan pembeda antar kelas bermasalah terhadap yang tidak bermasalah.

\section{DAFTAR PUSTAKA}

Alimaun, Imam (2015). Pengaruh Kedisiplinan terhadap Hasil Belajar Siswa Kelas V SD Se-Daerah Binaan R.A. Kartini Kecamatan Kutoarjo Purworejo. Skripsi: UNESS.

Amir. 2007. Dasar-Dasar Penulisan Karya Ilmiah. Surakarta: UNS Pres

B. Siswanto Sastrohadiwiryo. (2003). Manajemen Tenaga Kerja Indonesia. Jakarta: Bumi Aksara

Hadi, Sutrisno. (2001). Metodologi Research Jilid III. Yogyakarta: Andi Offset.

Hurlock Elizabeth B. (1988). Perkembangan Anak Jilid 2. (Alih Bahasa: Med. Meitasari Tjandrasa. Jakarta: Erlangga.

Iskandar. 2009. Metodologi Penelitian Kualitatif. Jakarta: Gaung Persada.

Kasihani Kasbolah. 2001. Penelitian Tindakan Kelas. Malang: Universitas Negeri Malang

Mohammad Mustari. (2011). Nilai Karakter Refleksi untuk Pendidikan Karakter. Yogyakarta: laks Bang Pressindo.

M. $\quad$ Rasyid $\quad$ Nur. 2015. http://www.kompasiana.com/mrasyidnur /manfaat-apel-tiap-pagi-disekolah_550f3fa1813311d434bc5fa8

Rustam, Mundilarto (2004) Penelitian Tindakan Kelas. Jakarta: Bumi Aksara

Suharsimi, Arikunto. (2006). Penelitian Tindakan Kelas. Jakarta: Bumi Aksara

Tu'u, Tulus. (2004). Peran Disiplin pada Perilaku dan Prestasi Siswa. Jakarta: Grasindo. 